\title{
The ethical implications of 2 John 10-11
}

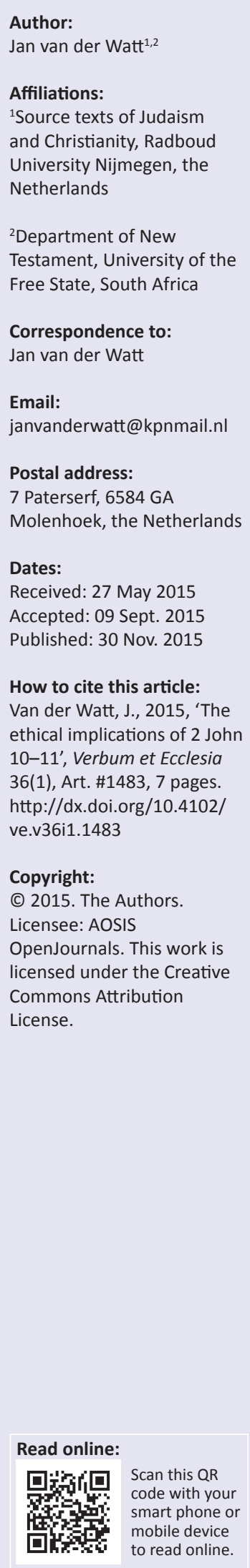

The imperative in 2 John 10-11 not to receive a visitor with a false doctrine into one's house is one of the most controversial prohibitions in the New Testament, especially in light of the commandment of love, ancient hospitality conventions, and modern-day expectations of open discussion. This raises the question what this prohibition is specifically about and whether hospitality is really asked for. This question is considered in some detail in this article. A widely held view is that the prohibition in 2 John 10 is not in line with generally accepted Christian ethics, since it militates against the attitude of love, care, and hospitality. This view is dominant in commentaries. This article aims at countering this view by proposing that the issue is not hospitality but endangering the identity and tradition of the group. This should be regarded as a positive Christian value.

Intradisciplinary and/or interdisciplinary implications: I challenge theological readings of 2 John 10-11 that regard the text as unchristian in its exhortation. The results of the research show that hospitality is not the communicative centre of the text, but protection of the group, which was a common feature, not only in Christianity, but also in the ancient world in general. The future discourse should now move from focusing on moral issues related to hospitality to issues related to preserving tradition within a religion.

\section{The problem}

One of the most controversial prohibitions in the New Testament is found in 2 John 10-11 which contains a direct imperative against receiving into one's house a visitor (probably a travelling preacher $^{1}$ ) who does not bring the teaching about Christ (v. 9) because this would imply cooperation with such a person. The relevant text reads:

If anyone comes to you and does not bring this teaching, do not receive him into your house or give him

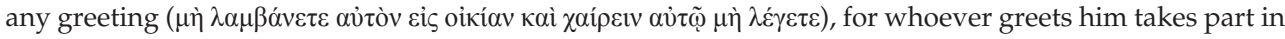

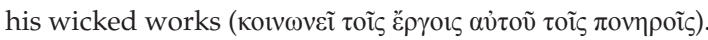

Apart from difficulties in determining who exactly these visitors were, the severity or even strangeness of this command is noted by many (Brown 1986:692-693; Kelly 1905:404-405; Pfeiffer \& Harrison 1962:ad loc.; Plummer 1886:139; Smalley 1984:333; Strecker 1989:346). It, for instance, creates tension with other Christian commandments like love and care (Jn 13:34; 1 Jn $3: 11 ; 4: 7-21$ ); it militates against the convention of ancient hospitality (Ac 16:15; Rm 12:13; Heb 13:2) and seems to stand in opposition to the recommendation in 3 John (Lenski 1966:569; Smalley 1984:334).

This resulted in a wide variety of responses stretching from a literal application to outright rejection of the prohibition (Akin 2001:233), speaking of the 'un-Christian nature of such a teaching' (Painter 2002:354). An interesting feature, that illustrates the partial influence of societal opinion on evaluating biblical content is that in the latter part of the 19th and earlier part of the 20th century the inclination (though not absolute) was more to accept a literal interpretation and application, while the opinion shifted in the middle of the 20th century to a more critical stance and even outright rejection of the prohibition (also not absolute).

Kelly (1905:405), for instance, takes a strong position, favouring the literal application of the prohibition for today:

To those who do not value Christ's name and word it must seem outrageous, especially in these liberal days, where man is all and Christ is little or nothing, and even professing Christians are so ready to say nothing about it. (cf. also Cocke 1895:148) 
More recently Hodges (1985:2908-2909) has argued that the 'modern inclination to be highly tolerant of religious differences' creates a problem, since by doing so 'this modern age ... has lost its convictions about the truth'. False teachers who actively partake in disseminating error should not be encouraged or helped at all.

Evaluating this position, Brown (1986:692) notes that 2 John 10 was used 'for slamming doors in the face of' door-to-door missionaries like the Jehovah's Witnesses, going back to the view that such biblical injunctions cannot be ignored. Brown (1986:693), for instance, quotes Alford saying that we are 'not at liberty to set aside direct ethical injunctions of the Lord's Apostles'.

A major figure like C.H. Dodd (1946:152) rejects the literal application of this prohibition on situations today by saying: 'We may similarly decline to accept the Presbyter's ruling here as a sufficient guide to Christian conduct', since, according to him, it is not in line with what the rest of the New Testament teaches. Brown (1986:693) sides with Dodd opining that this injunction cannot be applied directly to today's situation: 'Fierce exclusiveness, even in the name of truth, usually backfires on its practitioners'. According to Smith (s.a.:5293-5204) such behaviour could only lead to isolation and the inability to witness to others, apart from the fact that the prohibition is 'unchristian council, contrary to the spirit and teaching of the Lord'.

Brown (1986:693) further opines that the problem is that in almost every dispute in the church such claims are made and that drastic actions are usually justified by claiming that it is done for the sake of the truth. ${ }^{2}$ He then concludes: 'Dodd's question touches a real issue: "Does truth prevail the more if we are not on speaking terms with those whose view of the truth differs from ours - however disastrous their error may be?"'

Between these poles there are other voices, trying to solve the problem by pointing to the unique situation. Because of the nature of this injunction the unique nature of the situation is emphasised. Spence-Jones (1909:3) remarked at the beginning of the previous century that the apostle is giving directions to a particular Christian household during a particular crisis in the history of the Christian faith' (cf. Lenski 1966:569-571). Although he does not want to negate the command, he emphasises that the differences with current situations should be considered before applying the injunction today. Lücke (1837:332-333) already reflected on this in the first part of the 19th century and pointed out that John does not refuse hospitality to heathens or Jews, but to heretics who as Christians claimed a hospitable reception. Akin (2001:233) recently also opined that these verses are 'open to abuse and misunderstanding if removed from its immediate context', leading some to deem 'it unloving and worthy of rejection'.

2.Strecker (1989:346) reminds us that this is an inner-Christian conflict, since the false teachers were also carrying a message of Christ.
Because of these obvious tensions between the imperative in 2 John 10-11 and some core Christian values like hospitality, love or co-operation, modern commentators seriously reflect on the implications of 2 John 10 for present-day contacts with people of other mind than yourself, as is evident from the above discussion. Does 2 John 10 suggest a 'closed' situation where people who differ are not to be welcomed or conversed with, or should 2 John 10 for different reasons be interpreted as not applicable to present-day situations? Or is there perhaps a bigger principle behind the command that should be taken seriously?

Several questions beckon: (1) Although the remark is widely interpreted within the framework of ancient hospitality customs, it is a question whether hospitality is the main issue here; whatever the scenario, the implications should be considered. (2) If the issue is hospitality, is the issue here private or public (group) hospitality, or is this a false question? (3) What is the relationship between love, greeting and the command in 2 John 10-11? and (4) What is the relation between false teaching and social interaction?

\section{What if the visitors asked for hospitality?}

A contentious question is whether the prohibition in 2 John 10 is against showing hospitality or not. The majority of commentators assume this, although the view that this verse does not deal with hospitality is also defended. Both scenarios should be considered. Let us start with the assumption that hospitality customs form the background of the events narrated in 2 John 10-11.

Painter (2002:354), like many others (cf. e.g. Bultmann 1973:113-114; Kruse 2000:213-216; Watson 1989:106; Brown 1986:650-651), opines that the instruction given here 'is to be understood against the background of hospitality given to strangers and travellers in the ancient world'. For this reason, in virtually every respectable commentary or article dealing with these verses (or with $3 \mathrm{Jn}$ ), information is provided of what ancient hospitality entails. For our purposes a brief overview is also necessary, aimed at facilitating answers to our specific questions.

There is consensus that early Christians gathered in houses that were also ordinary family dwellings, that is, house churches (Rm 14-16; 1 Cor 1, 11; Col 4:15; cf. Malherbe 1983:94-96; Smith s.a.:5203; Gehring 2004; Banks 2012). Persons sufficiently well off would serve as donors, making their dwellings available to the Christian gathering (cf. Diotrepehes and Gaius in $3 \mathrm{Jn}$, or the 'elect Lady' in 2 Jn; cf. also Ac 18:1-3; Rm 16:3-5, 23; 1 Cor 16:19; Phlm 2-7). Christian house groups were thus formed, where (1) the ancient group-orientated practice of 'friends of friends' functioned, according to which related groups were encouraged to welcome one another's members, ${ }^{3}$ and (2) the hospitality

3. It is doubtful whether outsiders would make significant use of Christian hospitality during the early times. Judging from Pliny's letter to Trajan (110-114 CE) Christia meetings were rather secretive. The other side of the coin is that there is some evidence that people were apparently invited to (some of?) the meetings (1 Cor 14:16-25). 
customs of those days offered bases for boarding, lodging and further support for travellers, especially those who were part of the 'friends of friends' circle (Keener 1993:ad loc.; Malherbe 1983:102-103).

In this regard letters of recommendation played a central role, ${ }^{4}$ as we see in 3 John (Brown 1986:689-690). Malina (1986) describes the implications of letters of recommendation by saying:

The person writing a recommendation attests to the stranger bearing it on the basis of the world of honor of the attester. To reject the recommended stranger is, of course, a challenge to the honor of the recommender. It spurns his honor, and requires an attempt at satisfaction on his part, under pain of being shamed. (p. 187; cf. also Kruse 2000:215-216)

This meant that in such house churches the social boundaries were relatively porous (cf. Ac 20:20), although protected through the letters of recommendation. Hospitality also had the function of creatively presupposing a potential network of possible related and associated groups. This nevertheless emphasises that hospitality as such was a deeply social and relational act that had implications for future social interaction between those involved.

Considering the nature and impact of ancient hospitality conventions, Malina (1986:181) makes an important point: 'Hospitality might be defined as the process by means of which an outsider's status is changed from stranger to guest.' This happens by receiving the person into one's home and extending to the person certain rights and privileges linked to being part of that home and enjoying patronage from the host (Kruse 2000:213). Malina wants to restrict the practice of hospitality to outsiders who may be 'friends of friends', that is, those who carry a letter of recommendation, which presumes some form of prior relationship, direct or indirect (cf also Ebrard 1860:393). He therefore distinguishes hospitality from other social practices like welcoming your own family or close friends into your house.

Malina (1986) argues that once a person is allowed into the house different 'stages' of the process of hospitality should be distinguished:

The process would have three stages to it: (1) evaluating the stranger (usually with some test about whether guest status is possible); (2) the stranger as guest - the liminal phase; (3) from guest to transformed stranger (at times with another test). (p. 182)

At the basis of these stages lay certain social expectations, both of the host and the guest. ${ }^{5}$ Certain behaviour is expected, for instance, that the host protects the guest and that the guest

4.Brown (1986:690) speculates about the extent to which letters of recommendation were used in a close-knit group like the Johannine group.

5.It is expected of the guest to honour the practices, conventions and rules of the host. A host acts improperly if he (1) insults his guest or treats him with some enmity or rivalry, (2) if he does not protect the guest, (3) if the host does not give the required attention to his guest. A guest would break the rule and conventions if he (1) insults or challenges the host, (2) if he takes over the role of the host by doing he (1) insults or challenges the host, (2) if he takes over the role of the host by doing
things before he is invited, giving command or demanding things before it is offered things before he is invited, giving command or demanding thing
or refusing what is offered, namely food (Malina 1986:185). does not dishonour or shame the host. ${ }^{6}$ The way these social expectations are fulfilled determines whether a guest leaves as a friend or, possibly, as an enemy (Malina 1986:186), which would obviously determine future relations.

Another important point Malina (1986:185) makes is that '[w] hile hospitality does not entail mutual reciprocity between individuals, it can nevertheless be viewed as a reciprocal relationship between communities. Such hospitality to travelling Christians is both urged (see $\mathrm{Rm} \mathrm{12:13;} 1 \mathrm{Pt} 4: 9$ ) and much practiced (e.g. Ac 17:7; 21:17; 28:7; Rm 16:23)' (cf. also Malherbe 1983:92-103). This means that foreign visitors, being part of their own communities therefore represent these communities wherever they go. The visitors to the 'elect Lady' (2 Jn 10-11) therefore represented a group that is somehow related to the Lady's group, or else they would not have approached her, at least not for reasons of hospitality. Brown (1986:689) argues that these visitors could not have been 'haphazard' or even 'general missionaries' (cf. also Schnackenburg 1984:315-316; Ebrard 1860:393-395). They are part of a recent (Christological) development to which the Johannine groups are somehow 'related' and should now be warned against. Previously the 'Lady' perhaps offered hospitality without restriction since there was no such threat. Now the situation has changed and care should be taken as to whom she allows into her house.

Looking at the evidence in 2 John 10 it is possible that these possible (Du Rand 1997:173) visitors could qualify for

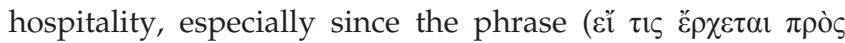
$\dot{v} \mu \tilde{\alpha} \varsigma-\varepsilon \dot{\imath}$ plus the indicative) suggests an 'open situation' with undetermined persons ( $\tau \iota \zeta$ ) arriving. According to the information about hospitality above, some sort of reciprocal relation between the visitors and the group of the 'elect Lady' should be assumed.7 The fact that no letter of recommendation is mentioned in 2 John might imply that these visitors were known to the 'Lady'. If Malina's view is valid that hospitality should be restricted to strangers who carry letters of recommendation, the case for hospitality is weakened.

If it is accepted that hospitality is at stake here, mainly two possibilities should be distinguished: (1) that it was a private house and that 'private hospitality' is prohibited or (2) that the people approach a house church $^{8}$ for congregational participation and that that form of 'group hospitality' is refused (Elwell 1995:ad loc.; Smalley 1984:333). It is doubtful whether these two options are exclusive of one another, since it seems logical that the 'travelling visitor' would need the hospitality of the house even after the meeting is finished. If not, the group most probably would have accommodated him or her in other ways. Malina (1986:185) indicates that

6.Malina (1986:182-183) remarks: 'To offend the protége or client is to offend the protector/patron. Thus the stranger is incorporated only through a personal bond with an established community member.'

7.Malina (1986:185-186), followed by Kruse (2000:215), explains that on the basis Malina (1986:185-186), followed by Kruse $(2000: 215)$, explains that on the basis determining how the host group will be treated when they are visiting the other group.

8.Cf. Romans 16:5; 1 Corinthians 16:19; Colossians 4:15; Philemon 2. 
visitors appealing for hospitality normally represented a group and not just an individual. In any case, the meetings were in a house where a host (the house owner) was in an authoritative position to make the final decision (as is the case with Diotrephes or even Gaius in 3 Jn). If these were travelling missionaries, they would normally have stayed longer than just the meeting and would have expected aid for their forward journey, which would involve the house owner (either in his capacity of private house owner or host to the gathering of Christians). Since the context also has religious undertones (these were false teachers) the idea of a purely private visit is not favoured.

Offering hospitality to someone in ancient times therefore involved a complex of conventions based on various expectations. The guest would receive protection, special status in the house, and could count on current and future support. In addition, acceptance would also indicate existing relations ('friends of friends') which would socially typify the host. It was therefore not a matter of a neutral 'hallo' and then 'goodbye'.

\section{What if hospitality conventions were not called upon?}

The above are broadly the situation in mind if hospitality conventions were called upon. As was mentioned earlier, the possibility exists that hospitality conventions should not be seen as the background to this situation. It is notable that in many cases it is simply assumed that hospitality should be regarded as the framework of this prohibition, without proper motivation. Let us consider some arguments that might suggest that hospitality conventions should not be the focus of the argument here.

\section{Treatment of deviating people in ancient gatherings: An example}

The second century document Inscriptiones Graecae II 1368 (dated around $178 \mathrm{CE}$ ) contains a minutes of a meeting of the Society of Iobacchi in Attica with a copy of the revised statutes (Ferguson 1990:108-110). Although the suggestion is by no means that there is a parallel or some link between 2 John and these statutes, there are some interesting points made in the statutes about the way in which the organisation and treatment of members were arranged. A few points will be highlighted: (1) membership was a community concern they voted on possible candidature. (2) If fees were not paid, a member would be 'excluded from the gathering' - they would not be allowed in. (3) Order was important (even at a meeting of the Bacchic society) - members were not allowed to sing or create disturbance, 'but each shall say and act his allotted part with all good order and quietness under the direction of the priest'. And further, 'If anyone start to fight or be found acting disorderly or occupying the seat of any other member or using insulting or abusive language', he will be fined. If anyone 'comes to blows' he will be excluded for a period. Even the officer who fails to eject the fighters will be punished. Making a speech without permission was a punishable offence. In the meetings an orderly officer also carried a thyrsus. He could place the thyrus beside a person who acts in a disorderly manner or who creates disturbance, indicating that such a person should leave the room. If the person disobeys or refuses he is 'put outside the front door' and punished. ${ }^{9}$

Several things should be noticed for our purposes. (1) Exclusion or expulsion from the meeting was the basic way of ensuring the orderly continuation of the meeting. If a person did not fit his role, he was put outside and even punished. (2) Discipline and order formed the basis of these meetings. In these statutes a major theme is the protection of the group and its activities against disorder or disruption. (3) The group as such had power to decide who they want to be a member and who should be excluded. Not hospitality conventions, but the power of the group's view(s) was dominant. The interests of the group were placed above any 'individual rights'.

If this was commonly accepted as practice, which Kloppenborg and Ascough (2011:55) seem to suggest, ${ }^{10}$ it has a lot so say about the situation of 2 John 10-11. Again it should be noted that the suggestion is not that the Bacchic situation and that of 2 John are in any way related. There are however interesting parallels, for instance, the way in which they protect their respective groups, inter alia by disallowing a deviating person contact with the group, or the acceptance of commonly shared rules or traditions may serve as pointers in understanding 2 John. This attitude of discouraging and breaking contact with deviating members is also confirmed in Christian documents. In Matthew 18:15-17 church discipline would involve exclusion of a person who did not align himself with the group's wishes. Paul makes the same suggestion in 1 Corinthians 5:4-5 where he recommends that a deviating person should be delivered to Satan. Titus 3:10 also calls for the exclusion of a divisive man. In Didache 11:1-2 or Ignatius' To the Smyrnaeans 4:1; 7:1 or 9:1 similar situations are envisaged. ${ }^{11}$ In light of what seems to be a common way of protecting the integrity of a group, exclusion or refusal to receive such divisive people in 2 John is not exceptional.

9.The above is only one example. Cf. also IG II 1275 (ca. beginning third century BCE) where the obligations of members of a thiasos are described. Accepting a law was done by mutual consent and after the law came into effect, the group had the right to punish trespassers of that law in different ways, inter alia by excluding them from to punish trespassers of that law in different ways, inter alia by excluding them from the group (cf. the discussion by Kloppenborg \& Ascough 2011:52-55). In a third century rabbinic document, t. Hullin 2:24 (for the text and discussion cf. Visotzky 2005:102-104), an episode is narrated where a prominent rabbi, Rabbi Eliezer, was arrested by the Romans for being a Christian. The judge found him not guilty, but it troubled the rabbi that he was regarded as a Christian. In response to a remark of Rabbi Akiba (i.e. 'Perhaps one of the heretics/Christians spoke some heresy which pleased you?') he realised that he transgressed by lending an ear to James of the village of Sikhnin who spoke about Christianity. By this he transgressed the words of Torah in Proverbs 5:8 and 7:26 which demand that one should keep away from harm and danger. 'Rabbi Eliezer used to say, "A person must always flee from the hateful (ki'ur) and all that resembles the hateful'". The attitude and practice of disassociating oneself from the danger presented by the 'hateful' is thus clearly attested within Jewish contexts also. Although this text most probably post-dates our situation, it represents an earlier attitude and consequent behaviour towards other-minded 'opponents'.

10.Kloppenborg and Ascough (2011:55) remark: 'It is common to find the imposition of fines and sometimes even temporary or even permanent exclusion of members who violate the rules of an association'. Cf. also IG II 1361.

11.Cf. also Ignatius' attitude in To the Ephesians 7:1; 8:1; 9:1; To the Smyrnaeans. 4:1; 5:1; 7:2. Cf. also Smalley (1984:334); Johnson (2011:158). Smith (s.a.:5203) compares this situation to John's behaviour towards Cerinthus. 


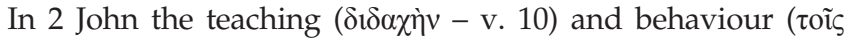
हैpyors - v. 11) of the visitors are judged negatively, and from the context it seems that social intercourse with these people would negatively influence the group and could endanger their mutual love. ${ }^{12}$ This is the problem addressed in verses 5-6 which is also contextually linked to the false teachers with a ötı-phrase in verse 7 . The reaction to such features that endangered the group in the Bacchic statutes was expulsion (i.e. severing social contact). According to these statutes the order within the group is of higher value than the presence of such a disrupting person. This is also the case in 2 John, as Smalley (1984:333) remarks: 'John is not therefore forbidding private hospitality, but rather an official welcome into the congregation, with the widespread opportunities which would then be available for the heretics to promote their cause.'

As such it is not a matter of hospitality, but of accepted social mechanisms protecting group identity and activity. ${ }^{13}$ The latter value overrides personal needs. This puts the command in 2 John 10 in another perspective. If it was the case that such people appealed to a Christian house church for hospitality then their right to hospitality is overruled ${ }^{14}$ by the fact that the group is of the opinion that their presence will endanger the group. If they were to be allowed they would have to be excluded in the end if they persisted in their destructive teachings. This allows for a legitimate refusal even for offering hospitality. ${ }^{15}$ So, hospitality as such is not negated here, but the conventions surrounding social activities within groups does not make reception of these people within the group an option, due to proven negative teachings and behaviour.

These visitors were indeed representatives of a related but opposing group. The refusal to receive or even greet them (2 Jn 11) amounts to more than expulsion. It boils down to making a doctrinal statement thereby confirming one's own position. By turning them away, their teachings are not only rejected, but any assistance for continuation of such teaching is refused (Schnackenburg 1984:317; Brown 1986:690; Kruse 2000:213; compare 2 Jn 11 with 3 Jn 8). No form of co-operation (koinõnia $)^{16}$ or association is offered. ${ }^{17}$ The reference to not

12.Lücke (1837:332-333) is of the opinion that such integration would lead to corruption of the truth and should therefore be discouraged.

13.Sometimes these categories are mixed. Smalley (1984:333-334), for instance, acknowledges that here it is not a case of private hospitality (such a distinction between private and public seems highly unlikely in ancient cultures) but public welcome in a congregation, but he nevertheless categorises and discusses it under 'hospitality as Christian virtue'. Clearer formulation is needed.

14.Bultmann (1973:114) opines that 'hospitality which was taken as obligatory elsewhere in primitive Christianity is not to be extended to itinerant heretics'. Cf. also Smith (s.a.:5204)

15.Ebrard (1860:393-395) already expressed this sentiment a century and half ago when he argued that the 'Lady' should neither have religious nor social contact with the heretics. 'The vain and aimless friendly intercourse with such liars must be broken off at once.' The question whether this injunction supposes 'excommunication' is pre-mature, since there is no evidence of a universal church or church ruling. What happens here happens on local level where the group of the 'Lady' seemingly has considerable freedom (Strecker 1989:347).

16.For the semantic range of koinõnia, see Ogereau (2014) who has convincingly shown that the word refers to co-operation that is based on relations.

17. Brown (1986:690-691) puts it in these words: 'The inhospitality urged by vv. 10-11 is part of the warfare between Christ and Antichrist, between the Spirit of Truth and the Spirit of Deceit ...'. In this 'war' harbouring the enemy in your 'camp' is not an option. greeting the person is also interpreted in many ways, but it basically refers to the 'cultivation of personal acquaintance and fraternal intercourse with the false teachers' (Elwell 1995:ad loc.; Lange 2008:192). ${ }^{18}$ This interpretation is in line with the idea that the injunction here does not aim at being rude, but at discouraging dangerous social interaction. ${ }^{19}$

This implies that the prohibition in 2 John 10-11 need not be seen as unchristian, unloving or harsh. It was an accepted way in which groups treated people who no longer operated within the confines of a particular group. This does not seem to and ought not be the problem for commentators. When it does become a problem, so it seems, is when the expectations of hospitality come into play. It is felt that it is rude or unloving not to offer this basic courtesy.

\section{Is this really a hospitality text?}

From the above arguments it is clear that the exclusion of the idea that this is a hospitality text clarifies a lot of problems. Are there other indications in this short text that hospitality is not the main focus or even a focus? I have argued this in more detail elsewhere and need not repeat the detail arguments (Van der Watt 2015). I will just briefly touch on one or two of the major arguments to indicate the line of thinking.

In considering a possible scenario two issues complicate matters: (1) why does the Presbyter only rejoice about some of the children walking in the truth? Are there others who do not, and if this is the case why not and what are they doing instead? (2) The Lady is advised not to receive the visitors into her home and not to give them any greeting. If these are unknown visitors, how would the Lady know what they stand for before receiving them into the meeting? She will then in any case be bound to greet them first. In reconciling these two problems, a scenario that the visitors were local and not foreign, and that some of the Lady's children already had contact with the false teachers (although not necessarily joining them yet), explaining why they do not behave in the truth, would not support a hospitality situation. Malina (1986:181) reminded us that hospitality in its true sense should be limited to outsiders who come with letters of recommendation from 'friends of friends'. If they were local, their position would have been known and the Lady would know not to receive or greet them. It would also explain why 'some' of the Lady's children did not walk in the truth, since they were not convinced about the convictions of the Lady on the religious level. They were still part of the physical family of the Lady, but did not share her religious views in which her group's behaviour was grounded. This tension in the family of the Lady is addressed by the emphasis on love and truth (2 Jn 5-6). If that is restored the false teachers would not

18.Lücke (1837:332-333) remarks, 'salutation ... [was] in the apostolic age, full of expression and signs of the Christian communion of faith and of brotherly-love'. Keener (1993:ad loc.) notes that in the Qumran society someone who provided for an apostate was expelled from that community together with the apostate.

19.The opposite is true of 3 John. There the visitors are of high repute, (at least from the perspective of the Presbyter - perhaps not from the perspective of Diotrephes: cf. Brown 1986:690), but Diotrephes is not acting according to the truth - his deeds cf. Brown 1986:690), but Diotrephes is not acting according to the truth - his deeds
are evil by not extending hospitality. These visitors will not endanger his group as such, although it seems as if Diotrephes was of another opinion. 
be able to destroy the lady's group and prevent them from winning the full award (2 Jn 8).

The identity of the visitors is not mentioned directly in the text, except for the fact that they are false witnesses. That they were visiting missionaries is an assumption, as is the focus on hospitality. Above it was argued that the situation presented in the text would make more sense if these false teachers were locals who did not appeal for hospitality but simply wanted to spread their false teaching within the group of the Lady.

This then results in another emphasis in reading the Letter. Questions about tensions between 2 John 10-11 and showing Christian love and courtesy, refusing basic hospitality are no longer relevant. The issue is rather what the reaction should be if a group is being penetrated by false teachers who will not only disrupt the group members that are apparently already under tensions regarding love among one another, but also have the potential of destroying them (2 Jn 8). As was argued above, there is ample evidence that such situations did not only threaten the Christian gatherings, but also other social groups like guilds. The response across the board seems to be the same: protect the group by breaking social contact if the evil doers do not want to conform, or at least until they are willing to conform and cease their destructive behaviour.

This option is indeed recognised in the debate. Commentators - even those who propose a hospitality framework for interpreting this text - are virtually unanimous that the essence of what 2 John 10 communicates is that the church group should be protected against harm..$^{20}$ For this reason, Schnackenburg (1984:316; cf. also Carson 1994:1412; Johnson 2011:159) does not want to interpret this injunction as contra to the commands of love for enemies (Mt 5:44-48) or reconciliation (Mt 5:23-25). He rather links this situation with the command of Jesus to his disciples to break contact with people who do not welcome the message of the Kingdom (Mt 10:14; Lk 10:10-11). ${ }^{21}$ Smalley (1984:334) argues along the same lines, claiming that the Presbyter neither prohibits love to others nor forbids all contact with the heterodox. Contact with them is necessary to change their minds (cf. Mt 9:10-12).22 According to Smalley (1984:334), the Presbyter is warning against the dangers of receiving heretics and thus strengthening their erroneous position, compromising the truth. Akin (2001:233; cf. Lange 2008:192; Kelly 1905:404405; Kistemaker 1986:383; Walls \& Anders 1999:238) agrees that the point in question is not prohibiting conversations with the 'spiritually confused' or with people with whom the message of Christ should be shared by allowing them

20.Plummer (1886:139) interprets it in an even wider sense, namely, that charity shown to one man should not harm others.

21.Carson (1994:ad loc.) remarks that in ancient times receiving somebody in one's home 'was to express one's approval of his teachings'. This should not be confused with expressing 'common courtesy to a doctrinal opponent'.

22.Ebrard (1860:394) has a harsh opinion about this, remarking, 'A Christian man should have to do with these deniers of Christ only for the one sole end of their conversion: as soon as he sees that his great object is spurned, he has nothing more to do with them'. to visit your house in order to confront them with the claims of Christ. No rudeness is suggested. It is rather to prohibit support and aid to false teachers and thus avoid disseminating error. This is essential for the health of the church.

\section{Some concluding remarks}

The question now is, what do we do with this information in our present-day situation? It surely has ethical implications. Views differ as to how these verses should be treated today, depending on the hermeneutical approach to the canonical text. Should the text have a direct mechanical impact on current events (a more fundamentalist approach); should analogy be the key; should it be regarded as an example that could be followed or not; is it just an interesting event in an early Christian situation? This is not the place to consider the hermeneutic complexities. It suffices to point out what the major thrust of the prohibition in 2 John 10-11 seemingly is, as I tried to argue.

Issues taken with the applicability of this prohibition on contemporary situations, as was described under point 1 at the beginning of the essay, should be more carefully considered. What the text exactly intends should be clarified and that point should then be considered, with its implications of course. It was shown above that this prohibition is not against love, care, and hospitality on an ordinary everyday level and should also not by analogy be applied to today's situations. The issue is what happens if a false teacher comes to your congregation and claims access to promote his views which might harm your group that is already under some communal stress (i.e., there are some tensions that point to lack of love or co-operation among the group). Allowing such a false teacher access might potentially harm or even destroy your congregation (2 Jn 8). Must such a person with the Christian group's blessing be allowed to continue with his work in your midst? Obviously the Presbyter does not think that is a good idea - to the contrary! ${ }^{13}$

A last remark: does this mean that the Johannine group should therefore not approach the world with their message or should not go into discussions with opponents? This is not what 2 John 10-11 implies or tries to address. The text does not focus on the missionary task of the Johannine group (which is clearly stated in Jn 17:18 or 20:21-22), but addresses another problem, namely, allowing threatening false prophets to destroy the congregation. A conclusion from silence regarding the absence of remarks in 2 John about missionary activities by the Lady's group itself should not be interjected into the situation as if it was an issue here.

\footnotetext{
23.I do not want to go into the criticism that in Christian debates virtually always consists of tho to go into the criticism that in Christian debates virtually always case but the Prespyter case, but the propbyter claried the situation, pointing out truth from falseness. He applies criteria like the traditional message (2 Jn 5-6), especially related to the traditional Christological confession. From there other convictions and correct behaviour are motivated.
} 


\section{Acknowledgements}

\section{Competing interests}

The author declares that he has no financial or personal relationships which may have inappropriately influenced him in writing this article.

\section{References}

Akin, D.L., 2001, 1, 2, 3 John, Broadman \& Holman Publishers, Nashville, TN. Banks, R.J., 2012, Paul's idea of community, Baker, Grand Rapids, MI. Brown, R.E., 1986, The Epistles of John, Doubleday, Garden City, NY.

Bultmann, R., 1973, The Johannine Epistles: A commentary on the Johannine Epistles, Fortress, Philadelphia, PA.

Carson, D.A., France, R.T., Moryer, J.A., \& Wenham, G.J., (eds.), 1994, New Bible commentary: 21st century edition, Inter-Varsity Press, Downers Grove, IL.

Cocke, A.R., 1895, Studies in the Epistles of John; or, The manifested life, Presbyterian Committee of Publication, Richmond, VA.

Dodd, C.H., 1946, The Johannine Epistles, Hodder \& Stoughton, London.

Du Rand, J.A., 1997, Johannine perspectives, Orion, Pretoria.

Ebrard, J.H.A., 1860, Biblical commentary on the Epistles of St. John, in continuation of the work of Olshausen, transl. W.B. Pope, Clark's Foreign Theological Library, Third Series, pp. 393-395, T\&T Clark, Edinburgh; Hamilton, Adams \& Co., London; John Robertson, Dublin.

Elwell, W.A., 1995, Evangelical commentary on the Bible, vol. 3, Baker, Grand Rapids, MI.

Ferguson, E., 1990, Backgrounds of early Christianity, Eerdmans, Grand Rapids, MI. Gehring, R.W., 2004, House church and mission, Peabody, Hendrickson, MA.

Hodges, Z.C., 1985, '2 John', in J.F. Walvoord \& R.B. Zuck (eds.), The Bible knowledge commentary: An exposition of the scriptures, vol. 2, pp. 2908-2909, Victor Books, Wheaton, IL.

Johnson, T.F., 2011, 1, 2, and 3 John, Baker, Grand Rapids, MI.

Keener, C.S., 1993, The IVP Bible background commentary: New Testament, InterVarsity Press, Downers Grove, IL.
Kelly, W., 1905, An exposition of the Epistles of John the Apostle, T. Weston, London.

Kistemaker, S.J., 2001, Exposition of James and the Epistles of John, Baker, Grand Rapids, MI.

Kloppenborg, J.S. \& Ascough, R.S., 2011, Greco-Roman associations: Texts, translations, and commentary, De Gruyter, Berlin.

Kruse, C.G., 2000, The Letters of John, Eerdmans, Grand Rapids, MI.

Lange, J.P., Schaff, P., Brain, K., \& Mombert, J.I., (eds.) 2008, A commentary on the Holy Scriptures: 1, 2, 3 John, Logos Bible Software, Bellingham, WA.

Lenski, R.C.H., 1966, The interpretation of the Epistles of St. Peter, St. John and St. Jude, Augsburg Publishing House, Minneapolis, MN.

Lücke, F., 1837, A commentary on the Epistles of St. John, Thomas Clark, Edinburgh.

Malherbe, A.J., 1983, Social aspects of the early church, Fortress, Philadelphia, PA.

Malina, B.J., 1986, 'The received view and what it cannot do: III John and hospitality', Semeia 35, 171-194.

Ogereau, J.M., 2014, 'Paul's koinõnia with the Philippians: Societas as a missionary funding strategy', New Testament Studies 60(3), 360-378. http://dx.doi. org/10.1017/S002868851400006X

Painter, J., 2002, 1, 2, and 3 John, Liturgical Press, Collegeville, MN.

Pfeiffer, C.F. \& Harrison, E.F. (eds.), 1962, The Wycliffe Bible commentary: New Testament, Moody Press, Chicago, IL.

Plummer, A., 1886, The Epistles of St. John, Cambridge University Press, Cambridge.

Schnackenburg, R., 1984, Die Johannesbriefe, Herder, Freiburg.

Smalley, S.S., 1984, 1, 2, 3 John, Word, Dallas, TX.

Smith, D., s.a., 'The Epistles of John', in The Expositor's Greek Testament: Commentary, vol. 5, pp. 5203-5204, George H. Doran Company, New York.

Spence-Jones, H.D.M. (ed.), 1909, 2 John, Funk \& Wagnalls, London.

Strecker, G., 1989, Die Johannesbriefe, Vandenhoeck \& Ruprecht, Göttingen.

Van der Watt, J.G., 2015, 'The situation in 2 John: A worried Presbyter', Journal of Early Christian History 5(2), forthcoming.

Visotzky, B.L., 2005, 'Methodological considerations in the study of John's interaction with first-century Judaism', in J.R. Donahue (ed.), Life in abundance, pp. 91-107, Liturgical Press, Collegeville, MN

Walls, D., \& Anders, D., 1999 / \& II Peter, I, II \& III John, Jude, Broadman \& Holman Publishers, Nashville, TN

Watson, D.F., 1989, 'A rhetorical analysis of 2 John according to Greco-Roman convention', New Testament Studies 35, 104-130. http://dx.doi.org/10.1017/ S002868850002453X 